\title{
The Value of Original Natural Stone in the Context of Architectural Heritage
}

\author{
Dolores Pereira ${ }^{1, *,+}$ and Brian Marker ${ }^{2,+}$ \\ 1 Department of Geology, University of Salamanca, Plaza de la Merced s/n, Salamanca 37008, Spain \\ 2 Independent consultant, 40 Kingsdown Avenue, London W13 9PT, UK; brian@amarker.freeserve.co.uk \\ * Correspondence: mdp@usal.es; Tel.: +34-923-294-498; Fax: +34-923-294-514 \\ $\dagger$ These authors contributed equally to this work.
}

Academic Editor: Carlos Alves

Received: 28 December 2015; Accepted: 19 February 2016; Published: 24 February 2016

\begin{abstract}
Natural stone is required for maintenance and repair of historically, archaeologically and culturally important structures to prevent deterioration due to weathering and use. Those that have national or World Heritage significance are historically and culturally important. Sometimes, severely damaged buildings may require extensive or complete restoration. The choice of stone should be appropriate in physical and aesthetic terms, ideally from the original source. Researchers, architects, those who specify contracts and other stakeholders need reliable information, but access to, and awareness of, important sources such as manuscripts, publications and collections of samples is often limited. Easier access to information is needed when planning and commissioning works that require the replacement of stone. Making important information more widely available and promoting awareness of the need to maintain adequate supplies of natural stone of suitable quality is a task for both national and international organizations including the Heritage Stone Task Group of IUGS and IAEG. This paper provides some illustrative examples and pointers towards some recent major publications, as well as describing current Heritage Stone Resource and European Union initiatives, all the while requesting further participation from colleagues in this field.
\end{abstract}

Keywords: natural stone; architectural heritage; building; Global Heritage Stone Resource

\section{Introduction}

This paper reviews aspects of natural stones that are required for maintenance and repair of historically, archaeologically and culturally important structures that have national or World Heritage significance. Proper repair and maintenance to prevent deterioration of structures due to weathering and use is essential but, from time to time, important buildings are severely damaged by events such as fires, earthquakes or military actions to the extent that they may be extensively or wholly restored $[1,2]$.

In either situation, the choice of stone should be appropriate in terms of physical performance and aesthetic appearance. Researchers, architects, those who specify contracts and other stakeholders need reliable information to achieve that. However, access to, and awareness of, important sources is often limited. Sources include publications, manuscripts, reference collections of rock samples and technical data in commercial websites and brochures. It is important to make important information more readily known and available as well as promoting awareness of the need to maintain adequate supplies of natural stone of suitable quality. That is a task for both national and international organizations.

There is space here only to provide some illustrative examples and pointers towards some recent major publications, and to describe current Heritage Stone Resource and European Union initiatives, all the while requesting further participation from colleagues. 


\section{Historical and Cultural Significance}

Natural stone has been used as a construction material since ancient times (e.g., since about 4700 BC in Egypt). Initially, these expensive materials were used for temples, tombs, palaces, civic buildings and major infrastructure as well as decoration and sculptures. Selection of stone was guided partly by suitability but was also influenced by personal prestige and social and mystic beliefs. For instance, green "marbles" (now identified as serpentinites) were related to joy in Egypt. Also, the traditional royal colour was blue until Queen Cleopatra had the walls of her banqueting hall in Alexandria adorned with red porphyry. Roman Emperors continued to use purplish-red stone encouraging wealthy people to surround themselves with beautiful objects made of porphyry to mark the importance of the owner [3]. These porphyries continued to be widely associated with nobility and Imperial monuments [4]. Several works have dealt with Egyptian rocks in general and porphyries in particular $[5,6]$. Another example is the mineral variety onyx which was regarded as being associated with instinct and intuition and was associated with business and management capabilities in ancient Greece and Rome [7].

The European Renaissance revived interest in European Classical culture. Royal Families became increasingly interested in stone as an expression of power and status in those classical styles. That led to an interest in preserving or initiating quarries to supply desirable materials for their projects. In particular, Carlos II of Spain was closely involved in securing his preferred stones for details (e.g., pavements, columns) in his palace. Similarly, in Sweden, the monarchy showed a close interest in natural stones, both for constructions and for gifts to hand to international dignitaries. A porphyry, discovered in Sweden in the 1730s, closely resembled the Egyptian red porphyry and became so desired that the Royal Family owned the porphyry-works from 1818 to 1856 [3].

\section{Some Reference Collections of Specimens}

Collections of samples of natural stones are an important source of information especially if they are accompanied by information on buildings and structures in which they have been used, technical properties and aesthetic characteristics. Unfortunately, that has rarely been the case but, even so, there are important exceptions.

One was developed for the Spanish Royal Family when, after a severe fire at their palace in 1734, they decided to build a new palace using as many "marbles and ornamental stones" as possible in construction [8]. They favoured stones from Spain but, if materials did not suit the King's aesthetic tastes, "marbles" were sought elsewhere, especially from Italy because that was the source of contemporary artistic and architectural inspiration. So, once again, the Roman preference for red stone became fashionable. Assembly of a set of samples was begun in 1740 and continued through the reigns of Kings Fernando VI, Carlos III and Carlos IV until 1759. The set is now part of the national heritage collections kept at the Royal Palace in Madrid (Figure 1). There are eight boxes with 40 compartments in each. Each compartment contains a sample of "marble" together with its location reference. Additional information is provided on a document included in each box, such as origin, distance from the quarry to the palace, (in Spanish leguas = leagues: originally, this was the distance that a person could walk in an hour) and abundance. Most samples came from Andalucía, Aragón and Catalonia. The collection is sometimes loaned for exhibitions such as that organized by the Colouste Gulbenkian foundation in Lisbon in 2014. It remains of great importance in establishing the selection of natural stones required for repair and maintenance by the royal authorities and has wider significance, but may not be well known outside Spain.

A systematic search of national quarries was undertaken for a specific stone, the diáspero sanguine, (similar to Rosso Diaspro Marble quarried in Sicily), that was referred to in archive documents as having been quarried in Andalucía, for the construction of the palace. The architect in charge was sent to Andalucía, visiting numerous quarries from 1761 to 1772 before finding a perfect match [9]. 


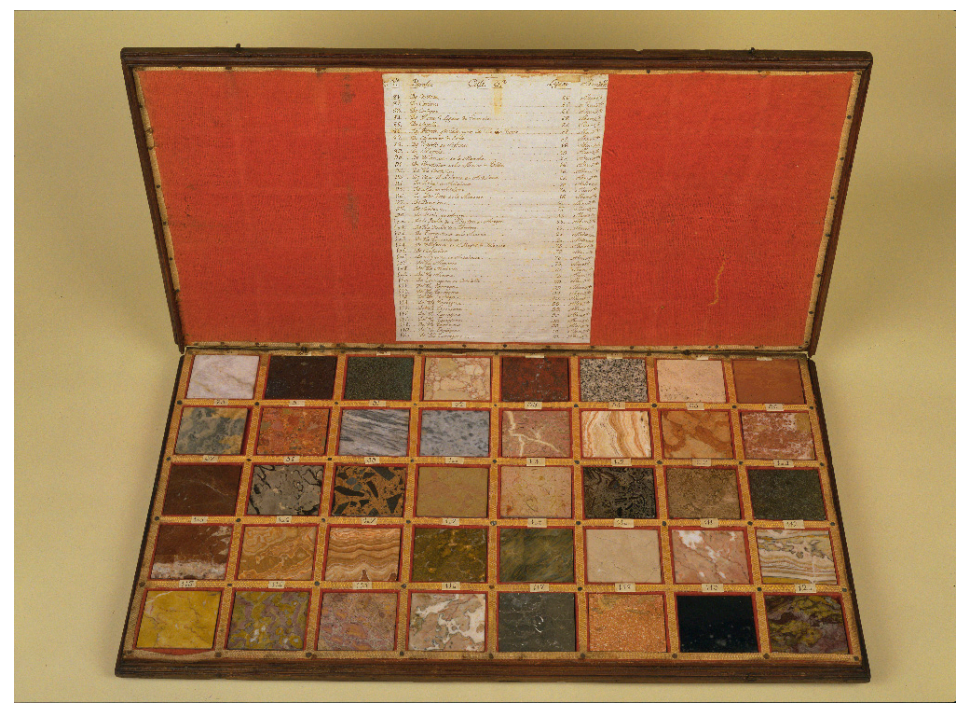

Figure 1. Showcase of marbles from the Spanish Royal Palace, Box number 3, inventory number 1013958. Copyright (C) Patrimonio Nacional.

An inventory of natural stones used for construction and for royal gifts such as vases in Baroque and Renaissance styles, known as "Jewels of the Dolphin" (the "Dolphin" being the French Grand Dauphin Louis de Borbón) survives. This is held by the Prado Museum in Madrid [10].

Another particularly valuable collection was made by Faustino Corsi [11], a lawyer who lived in Rome (1771-1846). He became a reputable judge but had artistic hobbies. He was passionate about the decorative stones that had been used in Ancient Rome and built up a collection of over a thousand polished specimens. He added descriptions, geological classifications, local names used by the marble cutters of contemporary Rome and ancient and contemporary names used by authors. In 1825, he published the Catalogo ragionato d'una collezione di pietre di decorazione [12] and, in 1827, he described each stone in his Supplemento [13]. In addition to those descriptions, Corsi drew attention to exceptional examples of stones that could be seen in the historic buildings of Rome. The collection is now held by the Oxford University Museum of Natural History [14] (Figure 2). It remains the most complete set of individual stones that were used in Roman times and for traditional architecture in Italy, related to examples of buildings and structures where they are best seen, but this, otherwise, exemplary work considered only polished decorative stones.

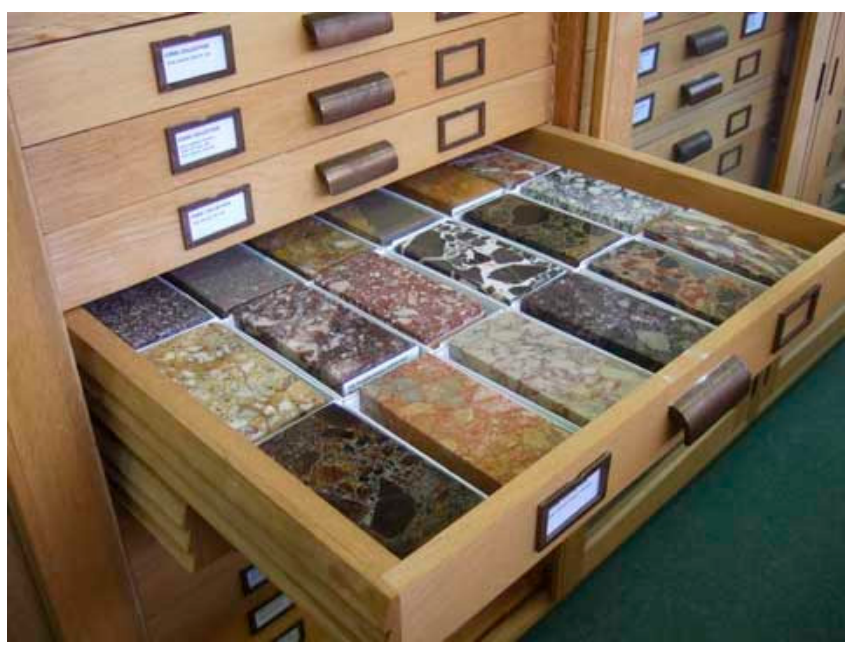

Figure 2. Drawers with Corsi's collection, by permission of Monica Price, Head of Earth Collections at Oxford University Museum of Natural History. 
Significant collections can be seen in other important museums such as the Louvre in Paris [8] and others are held by geological surveys and universities.

\section{Written Sources and Terminology}

There are many written sources of material on natural stones spanning several centuries but these are often not readily accessible. These include old manuscripts held in archives of libraries and museums where access may be restricted because of fragility. Also, the locations may not be widely known. Relevant literature has been aimed at various audiences (e.g., geoscientists, architects, historians and the general public) which may not be aware of publications aimed at the other sectors.

Another factor is language [15]. For instance, many important quarries and stones have been described in the regions of the Urals, Karelia, the Caucasus and around St Petersburg but are available only in Russian and, therefore, have not been widely disseminated outside Russian speaking areas. This is particularly important in relation to St Petersburg where a variety of stones from Scandinavia were imported for major buildings and art works [16,17].

Problems also arise through translations of terms. An example is "freestone" which, in English, means a stone used in masonry that can be readily carved with a chisel. The word "freemason" probably derives from that term as "one who is capable of carving freestone" [18] (in contrast to "roughstone", hard stones worked by the hard hewers or "rough masons"). The French term for "freestone" is "Pierre de Taille" or, in Spanish, "Piedra Franca". "Piedra Franca" literally means "honest stone", meaning stone that is easy to cut and carve. In Spain, this is applied to all stones of sedimentary origin that have uniform colour and ease of cutting/carving in order to obtain dimension stone blocks while, in England, the term has been generally restricted to limestones with those characteristics.

The earliest references to "freestone" are found in medieval documents when builders were choosing the best materials to construct magnificent cathedrals and castles. England had extensive suitable stone resources but, for historical reasons - the Norman invasion of England in 1066AD and subsequent expansion in major ecclesiastical and military building - a large volume of stone was imported from Caen in Normandy. Caen limestone was widely used for major buildings in Western Europe and more widely (e.g., Church of Saint-Étienne, Church of La Trinité, both Abbeys in Caen, Canterbury Cathedral, Reading Abbey, the Tower of London, the clock tower at Westminster Palace, and the Old South Church in Boston).

While the original French "Pierre de Taille" referred to the limestones extracted at Caen, over time, the meaning in adjacent countries, such as Spain, expanded to include other natural stones which had similar colours and were easy to carve. They included many sandstones, one of the most important of which was the Villamayor sandstone from Salamanca. However, other historically important natural stones are also known as "Piedra Franca" including calcarenite from Santa Pudia (Granada), limestone from Alava, and sandstones from Jaen and Cádiz [19]. All of these were used in construction of the Spanish architectural heritage and, superficially, share superficially similar exterior characteristics: several are known as "golden stones".

Very few papers have been published on individual freestones (or Pierre de Taille or Piedra Franca) and most of those are in relatively obscure journals or languages other than English.

Another issue is the use of the same name for more than one type of stone. Much stone is traded internationally and stone from developing countries often has the attraction of a lower price but this may not have a guaranteed quality characterization. Instances are known of stone being sold under European local names even though it comes from far away. The European Commission has recently launched a public consultation on the protection of names of specific important stones [20]. This protection would seek to make illegal within the EU to apply these names to other products, either man-made or imported from other geographical areas inside or outside the Union. This protection would be similar to that which already exists for agricultural products. In the case of natural stones, this protection would also be related to potential economic, social and cultural benefits. Several 
contributions regarding preservation of individual natural stones were made by European stone producers including Portland Stone, Carrara Marble, Bath Stone, and natural stone from Bourgogne.

\section{The Heritage Stone Task Group (HSTG) Initiative}

The HSTG was convened by the International Union of Geological Sciences at the 33th International Geological Congress (IGC), held in Oslo in 2008, in association with the International Association of Engineering Geology and the Environment (IAEG) Commission C-10 on Building Stones and Ornamental Rocks. The Group developed the concept of Global Heritage Stone Resource (GHSR) with the aims of improving awareness of the need for continuing supplies of important stone and protection of sources. This new formal international geological designation is being applied to important types of natural stone that have been widely used and/or have widespread cultural and architectural recognition [21].

This activity has already stimulated numerous presentations on specific natural stones from many parts of the world at international meetings (e.g., EGU 2013, EGU 2014, IAEG 2014, EGU 2015) and most have now been published. This has helped to increase awareness in the geosciences community of stones that were previously only appreciated nationally. Cooper et al. [21] set out the aim and objectives of the HSTG which included a protocol for describing natural stones that are proposed as candidates for GHSR status in terms of their occurrence, technical and aesthetic characteristics and examples of major heritage works in which they have been used. The first use of the protocol, for Portland Stone (United Kingdom), was published by [22] establishing the model that is being followed in subsequent proposals. A series of HSTG international events and publications are ongoing and include the European Geosciences Union General Assembly at Vienna and 35th International Geological Congress at Cape Town, both in 2016.

The first important volume dedicated only to GHSR candidate stones was published by the Geological Society of London as Special Publication 417. This volume was edited by Pereira et al. [23], and contained full descriptions of four natural stones from Spain, two from Sweden, one from Norway, two from Portugal, two from Slovenia, one from Brazil, one from Russia and five from Italy. The first edition of "Geoscience of the Built Environment", published in 2012 [24], also contained reports from HSTG activities on the Syracuse Limestone [25] and Verde Macael, a serpentinite from Andalucía, Spain. In this latter article, Navarro et al. described difficulties when dealing commercially with serpentinites which are commonly described as marbles which may lead some users to select stone incorrectly. Verde Macael had already been presented in different volumes to be recognized as a heritage stone [26].

The second major publication fully dedicated to heritage stones was a special issue of the journal Episodes, edited by Pereira, Kramar and Cooper [27], all of them board members of the HSTG at the time. This contained full descriptions of ten natural stones used in the architectural heritage: two from Sweden, two from Belgium, two from Spain, one from Russia, two from the United Kingdom and one from Australia.

Subsequently, Pereira and Pratt (in press) edited seven papers on stones from Spain, Brazil, Italy, Slovenia and Egypt based on papers presented at the European Geoscience Union (EGU) 2015 meeting. This issue also contains an introduction by Pereira and Marker highlighting the aesthetic and structural problems caused by the use of inappropriate stones in repair and maintenance [28].

\section{Physical and Aesthetic Properties}

Another aspect of raising awareness of appropriate stone for repair, maintenance and restoration of historic structures concerns the availability of reliable technical data. Replacement stone should ideally be of the same type as the original, or the nearest possible equivalent. Use of inappropriate stone can result in significant damage to the heritage. In order choose the correct stone, both the original stone and the potential replacements should be fully characterized. The stone industry has an important role in providing accurate technical and aesthetic information on their products. 
There is extensive literature on the variety, assessment, durability and resistance to weathering of natural stones which tend to be very individual in their behaviour. For instance, a serpentinite from Galicia (Verde Pirineo [29,30] behaves in a different way that a serpentinite from Andalucía (Verde Macael, [31]), or Rajasthan (Rajashtan Green, [32]) or Italy (green stones of the central Alps, [33]).

The Geological Society of London has strongly supported publication of many papers related to weathering and conservation of natural stones. In 2002, Siegesmund et al. [34] edited a volume dealing with weathering of natural building stones in different contexts, different weathering processes affecting the buildings, the fabric dependence of physical properties, biodeterioration, quality assessment, conservation of stones, and environmental conditions. Prǐkryl \& Smith [35] edited a book where authors analysed the causes, consequences, prevention and solution of several stone decay problems. Smith et al. [36] compiled information on limestones and the challenges for the preservation of heritage built with them. Prikkryl \& Tőrók [37] referred to natural stone resources that have been used for the construction of historical monuments. One of the major topics in this book was the availability of certain stone types that were used for monuments. Gómez-Heras et al. [38] presented a study on Oxford Stone and the consequences of its use in Oxford's historic buildings. In the same issue, Pereira et al. provided a paper on serpentinites from Galicia, Spain, reporting the unacceptable characteristics of these rocks for construction purposes, in contrast to some other serpentinites from elsewhere. Three tuffs from Italy were described by [39] to validate their use as replacement in some historical building. Figueiredo et al. [40] presented two Portuguese stones and Alloca et al. described the Vitulano marbles, which are important for the preservation of cultural heritage of Southern Italy [41].

JoAnn Cassar et al. edited a volume dealing with characterization and performance of natural stone in historic buildings [42]. Most of the papers in that book presented specific natural stones that had been used in architectural heritage, identifying the lithology and other characteristics of the stone, specific buildings where it had been used, and the provenance in parts of Spain, France, Belgium, Italy, and the United Kingdom.

\section{Conclusions}

Worldwide, the archaeological and historic stone built heritage has deep cultural significance. This has been recognised by national and World Heritage designation of important structures. These structures must be maintained, repaired and in some cases restored. However, there are many instances of inappropriate use of natural stone that does not match the original partly due to cost but also to lack of knowledge of the importance of using the same or very similar materials to those in the original fabrics to avoid physical or aesthetic damage. Barriers to progress include limited awareness of existing sources of information scattered across the technical and other literature, manuscripts and in historic collections of stone samples. Easier access to information is needed by researchers, constructors, funding organizations, architects and other stakeholders when planning and commissioning works that require the replacement of stone.

Increasing numbers of contributions are being published, partly through the Heritage Stone Task Group of the IUGS and IAEG, drawing wider attention to heritage stones, but these works are found in the geological literature while many relevant stakeholders are not geoscientists. The HSTG has developed a protocol for description of natural stones that is drawing together technical material and information on the major heritage structures in which the stones have been used. This may also help in stimulating awareness. Because stone is internationally traded, it is important to have proper technical descriptions of stone so that only appropriate types are used. It is significant that the EU is considering controlling the names that can be used to clarify what is "appropriate stone". It is increasingly important to summarize key information and to make this more readily available to both geological and non-geologist stakeholders to help to properly preserve the built heritage [43].

Geoscientists should discuss how this can be achieved and are invited to engage with the Heritage Stone Task Group. 
Acknowledgments: Thanks to the editor of this special volume, Carlos Alves, for inviting us to contribute to the issue. Brian R. Pratt made a critical revision of the first version of the manuscript, for which he is greatly acknowledged. Monica Price, from the Oxford University Museum of Natural History, showed me the Corsi collection, triggering the idea of this review. Lidia Catarino called attention to the exhibition of the Spanish treasures at the Colouste Gulbenkian Foundation in Lisbon. The Spanish National Heritage office provided a high-resolution picture of the stone collection from the Spanish Royal Palace. The authors are grateful for the continuous support of the International Union of Geological Sciences (IUGS) to Heritage Stone Task Group (HSTG) activities, and the International Geoscience Program (IGCP) 637 project for partially funding some of the HSTG meetings.

Author Contributions: Both authors contributed equally to this paper.

Conflicts of Interest: The authors declare no conflict of interest.

\section{References}

1. Pereira, D.; Marker, B. Repair and maintenance of natural stone in historical structures: The potential role of the IUGS Global Heritage Stone initiative. Geosci. Can. 2016, accepted.

2. List of World Heritage in Danger. Available online: http://whc.unesco.org/en/danger/ (accessed on 15 December 2015).

3. Wikström, A.; Pereira, D.; Lundqvist, T.; Cooper, B. The Dala (Älvdalen) porphyries from Sweden. Episodes 2015, 38, 79-84.

4. Bulak, A. "Porphyries" from Russia and Sweden Used in St Petersburg and Russian "porphyry" Used in Paris: Misuse of a Geological Term for some Possible Candidate as a Global Heritage Stone Resource. Episodes 2015, 38, 114-117.

5. Maxfield, V.; Peacock, D. The Roman Imperial Quarries-Survey and Excavation at Mons Porphyrites 1994-1998. Volume 1-Topography and Quarries; Egypt Exploration Society: London, UK, 2001; p. 339.

6. Harrell, J.A.; Storemyr, P. Ancient Egyptian quarries-An illustrated overview. In QuarryScapes: Ancient Stone Quarry Landscapes in the Eastern Mediterranean; Abu-Jaber, N., Bloxam, E.G., Degryse, P., Heldal, T., Eds.; Geological Survey of Norway Special Publication; Geological Survey of Norway: Trondheim, Norway, 2009; Volume 12, pp. 7-50.

7. Hamida, D. Onyx from Ain Smara (North-Eastern Algeria): A natural stone to be considered as a Global Heritage Stone. In Proceedings of the 2015 GSA Annual Meeting, Baltimore, MD, USA, 1-4 November 2015.

8. Tárraga Baldó, M.L. Mármoles y Rocas Ornamentales en la decoración del Palacio Real de Madrid. Arch. Esp. Arte 2009, 82, 367-392. [CrossRef]

9. Falcón Márquez, T. Documentos Sobre Jaspes Utilizados en el Escorial y en el Palacio Real de Madrid, Procedentes de la Cuenca Minera y su Entorno; I Congreso Nacional Cuenca Minera de Riotinto; Biblioteca Capitular y Colombina: Sevilla, Spain, 1988.

10. Angulo Iñiguez, D. Catálogo de las Alhajas del Delfin; Museo del Prado: Madrid, Spain, 1989; p. 267.

11. Corsi, F. Delle Pietre Antiche Libri Quattro; Da' Torchj di Giuseppe Salviucci e Figlio: Roma, Italy, 1828.

12. Corsi, F. Catalogo Ragionato D'una Collezione di Pietre di Decorazione; Da' Torchj del Salviucci: Roma, Italy, 1825.

13. Corsi, F. Supplemento al Catalogo Ragionato D'una Collezione di Pietre di Decorazione Formata in Roma Dall' Avvocato Faustino Corsi acquistata Dall' Onorevole Signor Stefano Jarrett Inglese e Posseduta Dall' Universita di Oxford; Da' Torchj del Salviucci: Roma, Italy, 1827.

14. Corsi Collection of Decorative Stones. Available online: http://www.oum.ox.ac.uk/corsi/ (accessed on 15 December 2015).

15. Pereira, D.; Cooper, B. Building stone as part of a World Heritage site: "Piedra Pajarilla" granite and the city of Salamanca (Spain). In Stone in Historic Buildings: Characterization and Performance; Geological Society Special Publications: London, UK, 2014; Volume 391, pp. 7-16.

16. Bulak, A. From the Granite Vase to the Door of the Palace. Aelvdalen Porphyry Manufacture, and Its Vases in St Petersburg; St Petersburg State University: St Petersburg, Russia, 2015; p. 128.

17. Gavrilenko, V. (Russian Pedagogical University, St. Petersburg, Russian Federation). Personal communication, 2015.

18. Schlosser, J. La Piedra Franca. Una Historia Masónica. Edición La Fraternidad: Tel Aviv, Israel, 2002. Available online: http:/ / www.librospdf.net/libro/la-piedra-franca-una-historia-masonica/50930/ (accessed on 28 December 2015). 
19. Pereira, D.; Navarro, R.; Baltuille, J.M. "Piedra Franca”: The same name for many different natural stones. Geophys. Res. Abstr. 2014, 16, EGU2014-31.

20. The EU single market. Available online: http://ec.europa.eu/internal_market/consultations/2014/geoindications-non-agri/index_en.htm (accessed on 17 December 2015).

21. Cooper, B.; Marker, B.; Pereira, D.; Schouenborg, B. Establishment of the "Heritage Stone Task Group" (HSTG). Episodes 2013, 36, 8-10.

22. Hughes, T.; Lott, G.K.; Poultney, M.J.; Cooper, B.J. Portland Stone: A nomination for "Global Heritage Stone Resource" from the United Kingdom. Episodes 2013, 36, 221-226.

23. Pereira, D.; Marker, B.; Kramar, S.; Cooper, B.; Schouenborg, B. Global Heritage Stone: Towards International Recognition of Building and Ornamental Stones; Geological Society Special Publications: London, UK, 2015; Volume 417, p. 275.

24. Special Issue "Geoscience of the Built Environment". Available online: http://www.mdpi.com/journal/ geosciences/special_issues/built_environ (accessed on 28 December 2015).

25. Giuffrida, A.; Ciliberto, E. Syracuse limestone: From the past a prospect for contemporary buildings. Geosciences 2013, 3, 159-175. [CrossRef]

26. Navarro, R.; Pereira, D.; Rodríguez-Navarro, C.; Sebastián, E. The Sierra Nevada serpentinites: The serpentinites most used in Spanish heritage buildings. In Global Heritage Stone: Towards International Recognition of Building and Ornamental Stones; Pereira, D., Marker, B., Kramar, S., Cooper, B., Schouenborg, B., Eds.; Geological Society Special Publications: London, UK, 2015; Volume 417, pp. 101-108.

27. Pereira, D.; Kramar, S.; Cooper, B. Global Heritage Stone Resource: An Update. Episodes 2015, $38,78$.

28. Pereira, D.; Pratt, B.R. Heritage Stones of the world. Geosci. Can. 2016, 43, 3-4.

29. Pereira, D.; Peinado, M.; Yenes, M.; Monterrubio, S.; Nespereira, J.; Blanco, J.A. Serpentinites from Cabo Ortegal (Galicia, Spain): A Search for Correct Use as Ornamental Stones; Geological Society Special Publication: London, UK, 2010; Volume 333, pp. 81-85.

30. Pereira, D. A report on serpentinites in the context of heritage stone resources. Episodes 2012, 35, 478-480.

31. Navarro, R.; Pereira, D.; Gimeno, A.; del Barrio, S. Verde Macael: A serpentinite wrongly referred to as a marble. Geosciences 2013, 3, 102-113. [CrossRef]

32. Pereira, D.; Peinado, M.; Blanco, J.A. Misuse of natural stone for construction and the consequences in buildings. Case of study of serpentinites. J. Mater. Civ. Eng. 2013, 25, 1563-1567. [CrossRef]

33. Cavallo, A. The "green stones" of Valtellina and Valchiavenna (central Alps, northern Italy). Geophys. Res. Abstr. 2015, 17, EGU2015-12319.

34. Siegesmund, S.; Weiss, T.; Vollbrecht, A. Natural Stone, Weathering Phenomena, Conservation Strategies and Case Studies; Geological Society Special Publications: London, UK, 2002; p. 205.

35. Prikryl, R.; Smith, B.J. Building Stone Decay: From Diagnosis to Conservation; Geological Society Special Publications: London, UK, 2007; p. 271.

36. Smith, B.J.; Gomez-Heras, M.; Viles, H.A.; Cassar, J. Limestone in the Built Environment: Present-Day Challenges for the Preservation of the Past; Geological Society Special Publications: London, UK, 2010; Volume 331, p. 249.

37. Prǐkryl, R.; Tőrők, A. Natural Stone Resources for Historical Monuments; Geological Society Special Publications: London, UK, 2010; Volume 333, p. 231.

38. Gomez-Heras, M.; Smith, B.J.; Viles, H.V. Oxford stone revisited: Causes and consequences of diversity in building limestone used in the historic centre of Oxford, England. In Natural Stone Resources for Historical Monuments; Prǐkryl, R., Tőrők, A., Eds.; Geological Society Special Publications: London, UK, 2010; Volume 333, pp. 101-110.

39. Nijland, T.G.; van Hees, R.P.J.; Bolondi, L. Evaluation of three Italian tuffs (Neapolitan Yellow Tuff, Tufo Romano and Tufo Etrusco) as compatible replacement stone for Römer tuff in Dutch built cultural heritage. In Natural Stone Resources for Historical Monuments; Prǐkryl, R., Tőrők, A., Eds.; Geological Society Special Publications: London, UK, 2010; Volume 333, pp. 119-128.

40. Figueiredo, C.; Folha, R.; Maurício, A.; Alves, C.; Aires-Barros, L. Contribution to the technological characterization of two widely used Portuguese dimension stones: The "Semi-rijo" and "Moca Creme" stones. In Natural Stone Resources for Historical Monuments; Prǐkryl, R., Tőrők, A., Eds.; Geological Society Special Publications: London, UK, 2010; Volume 333, pp. 153-164. 
41. Allocca, F.; Calcaterra, D.; Calicchio, G.; Cappelletti, P.; Colella, A.; Langella, A.; de' Gennaro, M. Ornamental stones in the cultural heritage of Campania region (southern Italy): The Vitulano marbles. In Natural Stone Resources for Historical Monuments; Prǐkryl, R., Tőrők, A., Eds.; Geological Society Special Publications: London, UK, 2010; Volume 333, pp. 219-231.

42. Cassar, J.; Winter, M.G.; Marker, B.R.; Walton, N.R.G.; Entwisle, D.C.; Bromhead, E.N.; Smith, J.W.N. Introduction to Stone in Historic Buildings: Characterization and Performance; Geological Society Special Publications: London, UK, 2013; Volume 391, p. 200.

43. Thomas, I. Quarrying Industry in Wales. A History; National Stone Centre: Middleton, UK, 2015; p. 224.

(C) 2016 by the authors; licensee MDPI, Basel, Switzerland. This article is an open access article distributed under the terms and conditions of the Creative Commons by Attribution (CC-BY) license (http:/ / creativecommons.org/licenses/by/4.0/). 